\title{
Pelaksanaan Diversi Terhadap Perkara Tindak Pidana yang dilakukan oleh Anak
}

\author{
Nasrullah \\ Fakultas Hukum, Universitas Muslim Indonesia \\ Koresponden, Email: nasrullah.arsyad@umi.ac.id
}

\begin{abstract}
ABSTRAK
Tujuan penelitian menganalisis pelaksanaan diversi terhadap perkara tindak pidana yang dilakukan oleh anak di Wilayah Hukum Gorontalo. Tipe penelitian ini adalah penelitian yuridis empiris dengan penekanan pada fakta yuridis yang ada di lapangan. Hasil penelitian menunjukkan bahwa hakikat pelaksanaan diversi dalam perkara tindak pidana yang dilakukan oleh anak yaitu diversi menekankan pada pemulihan kembali seperti pada keadaan yang semula, dilatarbelakangi keinginan untuk menghindari stigma anak sebagai pelaku kejahatan dan menghindari efek negatif terhadap jiwa dan perkembangan anak tersebut dalam keterlibatannya dalam sistem peradilan pidana. Pelaksanaan diversi di wilayah hukum provinsi Gorontalo belum efektif dikarenakan masih banyak perkara anak, ditangani secara prosedur formal dengan kata lain gagal atau tidak dilaksanakan diversi.
\end{abstract}

Kata Kunci: Diversi; Tindak Pidana; Anak

\section{ABSTRACT}

The research objective is to analyze the implementation of diversion of criminal cases committed by children in the Gorontalo Legal Area. This type of research is empirical juridical research with an emphasis on juridical facts in the field. The results showed that the nature of the implementation of diversion in criminal cases committed by children, namely diversion emphasizes recovery back to its original state, motivated by the desire to avoid the stigma of children as perpetrators of crime and avoid negative effects on the child's psyche and development in their involvement in the system. criminal justice. The implementation of diversion in the jurisdiction of Gorontalo province has not been effective because there are still many cases of children, handled in a formal procedure, in other words failing or not being carried out by diversion.

Keywords: Diversion; Criminal act; Child 


\section{PENDAHULUAN}

Penangananan anak yang berkonflik dengan hukum, senantiasa harus memperhatikan kondisi anak yang berbeda dari orang dewasa. Sifat dasar anak sebagai pribadi yang masih labil, masa depan anak sebagai aset bangsa, dan kedudukan anak di masyarakat yang masih membutuhkan perlindungan dapat dijadikan dasar untuk mencari suatu solusi alternatif bagaimana menghindarkan anak dari suatu sistem peradilan pidana formal, penempatan anak dalam penjara, dan stigmatisasi terhadap kedudukan anak sebagai narapidana (Pradityo, 2016).

Setiap tahun anak yang menjadi pelaku tindak pidana selalu meningkat, dalam kasus-kasus tertentu, anak yang menjadi pelaku menjadi perhatian khusus bagi aparat penegak hukum. Beberapa tahun terakhir ini masyarakat Gorontalo sering di gemparkan oleh berita-berita kejahatan dimana-mana, hal ini banyak diberitakan di media cetak maupun media elektronik antara lain seorang anak SMP mencuri disebuah toko, seorang pemuda memukul temannya karena cemburu, seorang pemuda melakukan percobaan pembunuhan karena dendam, sekelompok remaja berpesta miras disebuah rumah, seorang gadis remaja tertangkap setelah melakukan perbuatan aborsi dan lain-lain. Oleh karena itu, berbagai upaya pencegahan dan penanggulangan terhadap anak yang berhadapan dengan hukum, perlu segera dilakukan. Salah satu upaya pencegahan dan penanggulangan terhadap anak yang berhadapan dengan hukum saat ini melalui penyelenggaraan sistem peradilan pidana anak.

UUSPPA serta Peraturan Pemerintah Nomor 65 Tahun 2015 Tentang Pedoman dan Pelaksanaan Diversi dan Penerapan Anak Yang Belum Berumur 12 Tahun menegaskan bahwa kasus anak yang berhadapan dengan hukum wajib diupayakan diversi apabila kasus tersebut memenuhi syarat-syarat untuk dilakukannya diversi (Dewantary, 2016). Terlepas apakah sudah sesuai antara pasal-pasal yang mengatur tentang diversi di dalam UUSPPA dan Peraturan Pemerintah Nomor 65 Tahun 2015 Tentang Pedoman dan Pelaksanaan Diversi dan Penerapan Anak Yang Belum Berumur 12 Tahun dengan penerapannya selama ini, banyak pihak menganggap pentingnya untuk menerapkan diversi dalam penyelesaian kasus tindak pidana yang melibatkan anak (Tampubolon \& Jamba, 2020).

Adapun data awal yang diperoleh penulis dari Balai Pemasyarakatan Gorontalo terkait dengan Penelitian Kemasyarakatan Klien Anak Untuk Kepentingan Diversi di tingkat penyidikan mengalami fluktuasi dalam hal Pendampingan Pembimbing Kemasyarakatan terhadap Klien Anak, hal ini bisa dilihat pada tahun 2015 berjumlah 65 anak, tahun 2016 berjumlah 76 anak, sedangkan pada tahun 2017 jumlah anak yang didampingi pembimbing kemasyarakatan kurang sedikit dari tahun 2016 yaitu berjumlah 74 anak, adapun pada tahun 2018 berjumlah 25 anak. Berdasarkan data dari 4 tahun terakhir ini mengindikasikan bahwa di Gorontalo tindak pidana yang dilakukan oleh anak cukup tinggi.

Menurut penulis ada banyak tantangan yang dihadapi dalam mengupayakan diversi untuk kasus anak yang berkonflik dengan hukum. Misalnya, jenis tindak pidana yang melibatkan anak tidak dapat dilakukan diversi karena ancamannya lebih dari 7 tahun penjara dan itu merupakan alasan paling banyak kenapa upaya diversi tidak dapat dilakukan.

Di provinsi Gorontalo terkait dengan pelaksanaan diversi berdasarkan hasil penelusuran penulis di Polres Gorontalo terdapat pelaksanaan diversi yang gagal karena keluarga korban ingin lanjut ke pengadilan. Dari informasi yang penulis dapatkan, seorang anak berusia 16 tahun di desa Parungi, Kecamatan Boliohuto, dikeroyok empat orang temannya, hanya karena merasa tersindir karena korban mengajak berkelahi salah satu tersangka pengeroyok. 
Peristiwa pengeroyokan itu bermula Sabtu (11/5/2019) sore. Saat itu, keempat pelaku yang juga teman sekolah korban masing-masing berinisial GH (16), DF (15), KJ (16) dan FR (16), sedang berboncengan mengendarai 2 sepeda motor lewat di depan rumah korban, kemudian diteriaki korban menggunakan bahasa Gorontalo mengajak berkelahi GH, kesal dengan teriakan itu mereka pun datang menghampiri korban. Sempat terjadi cekcok, kemudian terjadi pemukulan oleh empat pelaku, Korban yang sendirian tak kuasa melawan karena salah satu pelaku menggunakan benda tumpul. Dia akhirnya terkapar dan dilarikan ke Puskesmas Boliohuto. Karena kondisinya cukup parah, pihak Puskesmas merujuk korban ke Rumah Sakit MM Dunda Limboto.

Kasus ini ditangani oleh Polres Gorontalo, upaya diversi yang digelar melibatkan semua pihak tersebut, berakhir gagal. Pihak keluarga korban meminta proses hukum tetap dilanjutkan.

"Upaya diversi sudah dilakukan oleh Unit Perlindungan Perempuan dan Anak Satreskrim Polres Gorontalo, namun pihak korban meminta kasus dilanjutkan," kata Kasat Reskrim Polres Gorontalo AKP Muhammad Kukuh Islami, SIK. dalam penanganan perkaranya, penyidik kepolisian juga berkoordinasi dengan Bapas, KPPAD, dan Dinas Sosial. "Penyidik tetap mengikuti prosedur penanganan perkara terkait anak di bawah umur" ucapnya. dia menyebut, berkas perkara kasus tersebut saat ini sudah dikirim ke kejaksaan. Jika sudah lengkap segera digelar tahap II penyerahan barang bukti dan tersangka.

Sekalipun diversi sudah dilakukan dan berproses bukan berarti pelaksanaannya tanpa kendala, melihat ada sejumlah tantangan yang harus dihadapi. Misalnya, dalam suatu perkara pidana anak tahun 2018 di Suwawa Kabupaten Bone Bolango yang di tangani Polres Bone Bolango, keluarga korban sudah setuju dilakukan diversi tapi memberikan syarat berupa penggantian sejumlah uang yang banyak, melihat syarat yang begitu berat keluarga pelaku tidak menyanggupinya. Oleh karenanya diversi tidak melulu harus melalui persetujuan pihak korban karena itu juga diatur dalam UUSPPA. Pasal 9 ayat (2) UUSPPA menjelaskan empat jenis tindak pidana yang dikecualikan untuk mendapat persetujuan pihak korban yaitu tindak pidana yang berupa pelanggaran; tindak pidana ringan; tindak pidana tanpa korban; atau nilai kerugian korban tidak lebih dari nilai upah minimum provinsi setempat.

\section{METODE PENELITIAN}

JTipe penelitian ini adalah penelitian yuridis empiris dengan penekanan pada fakta yuridis yang ada di lapangan. Yaitu penelitian hukum yang didasarkan pada kenyataan yang peneliti dapatkan sesuai dengan data yang ada di lapangan. Kemudian peneliti mengola data dengan menggunakan pendekatan analisis kualitatif deskritif yaitu mendeskripsikan data temuan penelitian dalam bentuk kalimat-kalimat berupa keterangan atau pernyataan-pernyataan dari responden sesuai dengan realitas yang ditemukan di lapangan.

Selanjunjutnya penelitian ini bersifat deskriptif, biasa juga disebut descriptif research atau taxonomic research. Penelitian deskriptif yaitu penelitian yang mengambarkan tentang fenomona obyek penelitian, dalam penelitian ini, analisis data tidak keluar dari lingkup sampel. Bersifat deduktif, berdasarkan teori atau konsep yang bersifat umum diaplikasikan untuk menjelaskan tentang seperangkat data, atau menunjukkan komparasi atau hubungan seperangkat data dengan seperangkat data yang lain. Oleh karena itu penelitian deskriptif berupaya mendeskripsikan sejumlah variabel berkenaan dengan masalah-masalah yang timbul dalam pelaksanaan penerapan diversi terhadap anak yang melakukan tindak pidana khususnya di provinsi Gorontalo. 


\section{PEMBAHASAN}

\section{Pelaksanaan Diversi Terhadap Perkara Tindak Pidana yang dilakukan oleh Anak di Wilayah Hukum Provinsi Gorontalo}

\section{Pelaksanaan Diversi di Tingkat Kepolisian}

Konsep prosedur pelaksanaan diversi pada tahap penyidikan dalam penyelesaian tindak pidana yang dilakukan oleh anak terdapat tiga bentuk, yaitu: Pertama, Musyawarah Polisi. Para pihak hanya terdiri dari polisi dan pelaku. Jenis tindak pidananya pelanggaran dan tindak pidana ringan (Ratomi, 2013). Sanksinya berupa peringatan informal, yaitu peringatan lisan dan peringatan tertulis. Peringatan informal tersebut tidak dicatat dalam suatu kesepakatan dan tidak perlu dimintakan penetapan ke pengadilan negeri. Kedua, Musyawarah Keluarga. Para pihak yang terlibat adalah polisi, pelaku dan/atau orangtua/walinya, dan pembimbing kemasyarakatan. Jenis tindak pidananya adalah tindak pidana ringan, tindak pidana tanpa korban dan tindak pidana yang nilai kerugian korban tidak lebih dari nilai upah minimum propinsi setempat. Sanksinya berupa peringatan formal yang dicatat dalam buku catatan kepolisian tapi tidak perlu disampaikan ke Pengadilan Negeri. Ketiga, Musyawarah Masyarakat (Nurhaliza, Liyus, \& Wahyudi, 2020).

Para pihak yang terlibat adalah polisi, pelaku dan/atau orangtua/walinya, korban dan/atau orangtua/walinya dan pembimbing kemasyarakatan serta masyarakat. Jenis tindak pidananya adalah tindak pidana yang diancam dengan pidana penjara di bawah 7 (tujuh) tahun dan bukan pengulangan tindak pidana serta bukan masuk kategori tindak pidana berupa pelanggaran, tindak pidana ringan, tindak pidana tanpa korban dan tindak pidana yang nilai kerugian korban tidak lebih dari nilai upah minimum propinsi setempat (Murdiana, 2017). Sanksinya berupa peringatan formal yang harus mendapatkan persetujuan dari korban dan/atau keluarganya jika korban masih di bawah umur. Hasil musyawarah itu kemudian dituangkan dalam sebuah kesepakatan diversi yang ditandatangani oleh para pihak. Kemudian hasil kesepakatan diversi itu disampaikan oleh atasan langsung polisi kepada Pengadilan Negeri untuk memperoleh penetapan. Setelah menerima penetapan dari pengadilan, Penyidik menerbitkan surat penetapan penghentian penyidikan.

Berdasarkan Pasal 12 ayat (1) Peraturan Pemerintah Nomor 65 Tahun 2015 tentang Pedoman Pelaksanaan Diversi dan Penanganan Anak Yang Belum Berumur 12 (Dua Belas) Tahun, menyatakan: "Dalam jangka waktu 1 x 24 (satu kali dua puluh empat) jam terhitung sejak surat perintah penyidikan diterbitkan, Penyidik menyampaikan surat pemberitahuan dimulainya penyidikan kepada Penuntut Umum. Dalam melaksanakan penyidikan, Penyidik berkoordinasi dengan Penuntut Umum dalam jangka waktu paling lama 1 x 24 (satu kali dua puluh empat) jam terhitung sejak dimulainya penyidikan. Dalam hal dilakukanlah upaya Diversi, Penyidik memberitahukan upaya Diversi tersebut kepada Penuntut Umum dalam jangka waktu paling lama 1 x 24 (satu kali dua puluh empat) jam terhitung sejak dimulainya upaya diversi.

Ketika dimulainya penyidikan, Penyidik dalam jangka waktu paling lama 1 x 24 (satu kali dua puluh empat) jam mengirim surat kepada pihak Balai Pemasyarakatan (Bapas) untuk meminta Pembimbing Kemasyarakatan untuk hadir mendampingi anak dan melakukan penelitian kemasyarakatan atau yang biasa disebut dengan Litmas. Dalam jangka waktu paling lama 3 x 24 (tiga kali dua puluh empat) jam terhitung sejak tanggal diterimanya surat permintaan dari Penyidik, Pembimbing Kemasyarakatan wajib menyampaikan hasil 
penelitian kemasyarakatan dan Pekerja Sosial Profesional wajib menyampaikan hasil laporan sosial kepada penyidik.

Dalam jangka waktu paling lama 7 (tujuh) hari terhitung sejak dimulainya penyidikan, penyidik yang berkepentingan wajib memberitahukan dan menawarkan kepada Anak dan/atau orang tua/Wali, serta korban atau Anak Korban dan/atau orang tua/Wali untuk menyelesaikan perkara melalui Diversi. Dan ketika telah terjadi kesepakatan pelaksanaan diversi, segera Penyidik menentukan tanggal dimulainya musyawarah diversi kemudian menyampaikan berkas perkara dan berita acara upaya Diversi kepada Penuntut Umum.

Proses diversi sendiri dilaksanakan dalam jangka waktu paling lama 30 (tiga puluh) hari terhitung sejak tanggal dimulainya Diversi. Berdasarkan Pasal 15 ayat (3) PP Nomor 65 tahun 2015 Pelaksanaan musyawarah Diversi melibatkan: Penyidik; Anak dan/atau orang tua/Walinya; korban atau Anak Korban dan/atau orang tua/Walinya; Pembimbing Kemasyarakatan; dan Pekerja Sosial Profesional (Fikri, 2020).

Menurut bapak Helfis Ntuiyo, selaku Kepala Unit Perlindungan Perempuan dan Anak pada Satreskrim Polres Bone Bolango menyatakan bahwa pada umumnya dalam hal musyawarah diversi anak yang ditangani pihaknya di hadiri kepala desa setempat dimana anak itu bertempat tinggal.

Musyawarah diversi dilaksanakan di suatu ruangan yang representatif untuk semua peserta musyawarah. Musyawarah diversi sendiri dipimpin oleh penyidik yang menanangi kasus anak yang berhadapan dengan hukum yang bertindak sebagai fasilitator dan pembimbing kemasyarakatan yaitu perwakilan dari bapas sebagai wakil fasilitator. Musyawarah Diversi dibuka dengan membacakan hasil penelitian kemasyarakatan atau litmas oleh pembimbing kemasyarakatan sekaligus rekomendasi dari pihak bapas. Rekomendasi itu merupakan hasil dari sidang Tim Pengamat Pemasyarakan (TPP) Balai Pemasyarakatan. Dalam hal proses musyawarah diversi tidak mencapai kesepakatan, penyidik membuat laporan dan berita acara proses diversi dan tugas Penyidik selanjutnya adalah mengirimkan berkas perkara kepada penuntut umum untuk dilanjutkan ke proses peradilan pidana selanjutnya.

Dalam hal musyawarah diversi mencapai kesepakatan, Surat Kesepakatan Diversi ditandatangani oleh Anak dan/atau orang tua/Wali, korban, Anak Korban dan/atau orang tua/Wali, Penyidik, Pembimbing Kemasyarakatan, dan Pekerja Sosial Profesional dan Seluruh proses pelaksanaan Diversi dicatat dalam berita acara diversi, Dan penyidik menyampaikan Surat kesepakatan diversi dan berita acara diversi kepada atasan langsung penyidik dan dalam jangka waktu paling lama 3 (tiga) hari terhitung sejak tanggal dicapainya kesepakatan diversi, atasan langsung penyidik mengirimkan Surat Kesepakatan diversi dan berita acara diversi kepada ketua pengadilan negeri setempat untuk memperoleh penetapan, Kemudian ketua pengadilan negeri setempat mengeluarkan penetapan kesepakatan diversi dan sekaligus menetapkan status barang bukti dalam jangka waktu paling lama 3 (tiga) hari terhitung sejak tanggal diterimanya Surat Kesepakatan diversi dan berita acara diversi. Penetapan itu disampaikan kepada Penyidik dan Pembimbing Kemasyarakatan dalam jangka waktu paling lama 3 (tiga) hari terhitung sejak tanggal penetapan.

Tahap selanjutnya penyidik berkewajiban untuk meminta para pihak untuk melaksanakan kesepakatan diversi setelah menerima penetapan dari ketua pengadilan negeri setempat.

Untuk mengetahui pelaksanaan diversi di tingkat kepolisian, berikut ini adalah gambaran sesuai penelitian di lapangan, data diversi yang penulis dapatkan di lokasi penelitian yaitu 
Polres Gorontalo, Polres Gorontalo Kota dan Polres Bone Bolango dapat dilihat pada tabel berikut ini :

Tabel 1 Pelaksanaan Diversi di Kepolisian Tahun 2016-2019

\begin{tabular}{cccccccc}
\hline \multirow{2}{*}{ No. Tahun } & \multicolumn{5}{c}{ Lokasi Penelitian } \\
\cline { 3 - 8 } & & Polres Gorontalo & $\begin{array}{c}\text { Poles Gorontalo } \\
\text { Kota }\end{array}$ & \multicolumn{2}{c|}{$\begin{array}{c}\text { Polres Bone } \\
\text { Bolango }\end{array}$} \\
\cline { 3 - 8 } & & $\begin{array}{c}\text { Jumlah } \\
\text { Perkara }\end{array}$ & Diversi & $\begin{array}{c}\text { Jumlah } \\
\text { Perkara }\end{array}$ & Diversi & $\begin{array}{c}\text { Jumlah } \\
\text { Perkara }\end{array}$ & Diversi \\
\hline 1. & 2016 & 30 & 17 & 15 & 7 & 24 & 19 \\
2. & 2017 & 13 & 3 & 8 & 2 & 22 & 7 \\
3. & 2018 & 12 & 3 & 11 & 4 & 11 & 5 \\
4. & 2019 & 17 & 9 & 20 & 4 & 18 & 10 \\
\hline \multicolumn{2}{|c}{ Jumlah } & 72 & 32 & 54 & 17 & 75 & 41 \\
\hline
\end{tabular}

Sumber : Data primer yang diolah, tahun 2020

Berdasarkan data di atas dari tahun 2016 sampai dengan tahun 2019 di tiga lokasi penelitian menunjukkan bahwa anak yang berkonflik dengan hukum berjumlah 201 kasus. Sementara jumlah yang berhasil di diversi sebanyak 90 kasus. Artinya data ini menunjukkan bahwa dari 201 kasus anak yang berkonflik dengan hukum, sebanyak 111 yang tidak dilaksanakan diversi atau dengan kata lain gagal diversi. Polres Bone Bolango paling banyak dalam menyelesaikan kasus anak yang berkonflik dengan hukum melalui diversi yaitu sebanyak 41 kasus kemudian Polres Gorontalo sebanyak 32 kasus.

Persentase perbandingan penyelesaian anak yang berkonflik dengan hukum melalui diversi dengan tidak dilaksanakan diversi atau gagal diversi dapat dilihat pada digram berikut ini :

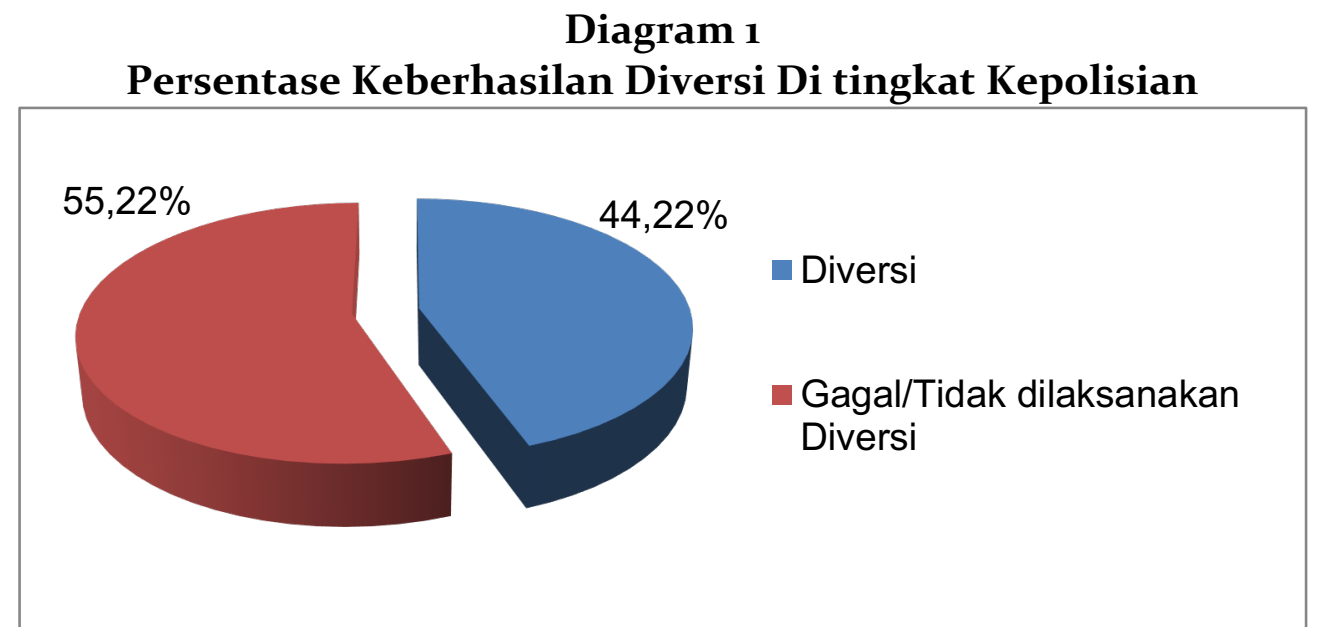

Sumber: Data primer diolah tahun 2020

Berdasarkan persentase di atas dapat ditarik kesimpulan bahwa dalam tingkat kepolisian sebagaian besar kasus anak yang berkonflik dengan hukum tidak dapat diselesaikan melalui diversi. Data diatas, menunjukkan bahwa penyelesaian kasus anak yang berkonflik dengan hukum melalui jalur diversi belum efektif di tingkat kepolisian. Hal ini bisa dilihat bahwa 55,22 persen gagal atau tidak dilaksanakan diversi berbanding 44,77 persen diversi berhasil. 
Menurut bapak Helfis Ntuiyo, selaku Kepala Unit Perlindungan Perempuan dan Anak pada Satreskrim Polres Bone Bolango jika ada kasus tindak pidana yang pelakunya adalah seorang anak maka diupayakan diversi. Ketika dalam masa penyidikan dilakukan, biasanya antara korban dan pelaku melakukan musyawarah, dari beberapa kasus sebagian berkas perkaranya dilimpahkan ke pihak kejaksaan negeri. Pada umumnya musyawarah ini terjadi karena bantuan pihak ketiga dalam hal ini kepala desa (ayahanda) atau tokoh masyarakat.

Masih adanya kasus yang diteruskan ke pihak kejaksaan dapat dikatakan kewenangan kepolisian untuk menerapkan restorative justice dalam penanganan anak yang melakuan tindak pidana belum dipergunakan secara maksimal. Ini adalah fakta yang menunjukkan pihak kepolisian belum menggunakan pendekatan restoratif dalam menangani perkara anak. Ada beberapa alasan mengapa pihak kepolisian tidak menggunakan pendekatan restoratif secara maksimal, hal ini karena ada beberapa kasus anak yang wajib diteruskan ke kejaksaan seperti kasus pemerkosaan atau pencabulan dan narkoba. Sedangkan untuk kasus tindak pidana ringan seperti kasus pencurian biasa, penganiayaan dan pencabulan biasa biasanya dilakukan pendekatan restoratif dengan melibatkan keluarga pelaku, keluarga korban dan tokoh-tokoh masyarakat setempat.

Masih menurut bapak Helfis Ntuiyo, selaku Kepala Unit Perlindungan Perempuan dan Anak Satreskrim Polres Bone Bolango, diversi bisa diterapkan pada kasus yang pelakunya anak biasanya pada kasus tindak pidana ringan, tindak pidana yang ancaman pidana di bawah 7 (tujuh) tahun dan bukan merupakan tindak pidana pengulangan seperti yang tertuang dalam pasal 7 UUSPPA.

Analisis penulis melihat fenomena bahwa masih banyak terdapatnya kasus anak yang berkonflik dengan hukum yang gagal atau tidak dilaksanakan diversi di provinsi Gorontalo dikarenakan kasus tidak pidana yang dilakukan anak adalah bukan yang tergolong kasus perkara yang dapat di diversi yaitu ancamannya hukumannya diatas 7 (tujuh) tahun dan ada beberapa kasus yang merupakan tindak pidana pengulangan. Selain itu memang pihak korban tidak mau berdamai dan ingin melanjutkan kasus itu ke penyelesaian formal. Terkait dengan kontroversi mengenai pencantuman tindak pidana pengulangan menurut penulis mengingat bahwa pengulangan tindak pidana (recidive) yang dilakukan oleh anak pada umumnya disebabkan oleh pengaruh lingkungan dan bukan karena bakat jahat dari anak itu sendiri, maka pemberatan pidana pada pengulangan tindak pidana yang dilakukan anak tidak perlu dibatasi atau minimal diberi kesempatan lagi anak itu untuk memperbaiki dirinya.

\section{Pelaksanaan Diversi di Tingkat Kejaksaan Negeri}

Tata Cara Pelaksanaan Diversi oleh Jaksa Penuntut Umum Berdasarkan Peraturan Jaksa Agung Republik Indonesia No: PER-0o6/A/J.A/o5/2015 tentang Pedoman Pelaksanaan Diversi pada Tingkat Penuntutan. Pengaturan mengenai tata cara pelaksanaan Diversi oleh jaksa Penuntut Umum selain menggunakan Undang-Undang Sistem Peradilan Anak juga menggunakan Peraturan Jaksa Agung Republik Indonesia No: PER-oo6/A/J.A/o5/2015 tentang Pedoman Pelaksanaan Diversi pada Tingkat Penuntutan. Maksud dan Tujuan dibuatnya Perja terdapat didalam BAB 1 Pendahuluan yang intinya adalah acuan bagi Jaksa Penuntut Umum dalam menyelesaikan perkara anak pada tingkat penuntutan dengan kewajiban upaya Diversi berdasarkan keadilan restoratif, yang bertujuan untuk tercipta persamaan persepsi dan keseragaman standar teknis atau pun administrasi untuk semua jaksa Penuntut Umum yang melaksanakan Diversi pada tingkat penuntutan. Proses pelaksanaan Diversi terdapat dalam BAB III Perja. 
Musyawarah Diversi dilaksanakan di RKA yaitu Ruang Khusus Anak, dalam hal ini Jaksa Penuntut Umum sebagai fasilitator mengawali musyawarah dengan perkenalan para pihak, kemudian menjelaskan maksud dan tujuan Diversi, peran fasilitator, tata tertib musyawarah, penjelasan waktu dan tempat serta dugaan tindak pidana yang didakwakan terhadap anak. Kemudian para pihak yang bersangkutan dalam pelaksanaan Diversi, di berikan kesempatan oleh fasilitator untuk menyampaikan pendapat, saran, dan tanggapan. Setelah dilaksanakannya Diversi kemudian dibuatlah Berita Acara Diversi yang ditandatangani fasilitator dan para pihak kemudian dilaporkan ke Kepala Kejaksaan negeri atau Kepala Cabang Kejaksaan Negeri. Jika diversi tidak tercapai kesepakatan maka Jaksa Penuntut Umum melimpahkan perkara disertai lampiran Berita Acara Diversi dan Hasil Penelitian Kemasyarakatan ke Pengadilan Negeri.

Dalam jangka waktu 7 x 24 (tujuh kali dua puluh empat) jam terhitung sejak penyerahan tanggung jawab atas Anak dan barang bukti, Penuntut Umum menawarkan kepada Anak dan/atau orang tua/Wali, serta korban atau Anak Korban dan/atau orang tua/Wali untuk menyelesaikan perkara melalui Diversi. Ketika disepakati oleh semua pihak untuk melakukan diversi maka Penuntut Umum menentukan tanggal dimulainya musyawarah Diversi. Akan tetapi ketika para pihak tidak sepakat untuk melakukan Diversi, maka Penuntut Umum wajib menyampaikan berita acara upaya Diversi dan melimpahkan perkara ke pengadilan (Wicaksana \& Pujiyono, 2015).

Proses diversi sendiri dilaksanakan dalam jangka waktu paling lama 30 (tiga puluh) hari terhitung sejak tanggal dimulainya diversi. Proses diversi dilakukan dengan cara musyawarah dan yang terlibat dalam diversi itu : Penuntut Umum, Anak dan/atau orang tua/Walinya, korban atau Anak Korban dan/atau orang tua/Walinya, Pembimbing Kemasyarakatan, dan Pekerja Sosial Profesional. apabila dikehendaki oleh Anak dan/atau orang tua/Wali, pelaksanaan musyawarah Diversi dapat melibatkan masyarakat yang terdiri atas : tokoh agama, guru, tokoh masyarakat, Pendamping; dan Advokat.

Musyawarah Diversi dipimpin oleh Penuntut Umum sebagai fasilitator dan Pembimbing Kemasyarakatan sebagai wakil fasilitator. Dalam hal proses musyawarah Diversi tidak mencapai kesepakatan, Penuntut Umum membuat laporan dan berita acara proses Diversi. Selanjutnya Penuntut Umum melimpahkan perkara kepada pengadilan. Dalam hal musyawarah mencapai kesepakatan, Surat Kesepakatan Diversi ditandatangani oleh Anak dan/atau orang tua/Wali, korban, Anak Korban dan/atau orang tua/Wali, Penuntut Umum, Pembimbing Kemasyarakatan, dan Pekerja Sosial Profesional. Serta seluruh proses pelaksanaan Diversi dicatat dalam berita acara Diversi (Chandra, Baharuddin \& Djanggih, 2020).

Ketika diversi mencapai kesepakatan, Penuntut Umum menyampaikan Surat Kesepakatan Diversi dan berita acara Diversi kepada atasan langsung Penuntut Umum. Kemudian dalam jangka waktu paling lama 3 (tiga) hari terhitung sejak tanggal dicapainya kesepakatan Diversi, atasan langsung Penuntut Umum mengirimkan Surat Kesepakatan Diversi dan berita acara Diversi kepada Ketua Pengadilan Negeri untuk memperoleh penetapan. Ketua Pengadilan Negeri mengeluarkan penetapan kesepakatan Diversi sekaligus menetapkan status barang bukti dalam jangka waktu paling lama 3 (tiga) hari terhitung sejak tanggal kesepakatan Diversi dan berita acara Diversi diterima. Penetapan diversi itu disampaikan kepada Penuntut Umum dan Pembimbing Kemasyarakatan dalam jangka waktu paling lama 3 (tiga) hari terhitung sejak tanggal penetapan Ketua Pengadilan Negeri setempat. Kemudian para pihak diminta untuk melaksanakan kesepakatan diversi setelah menerima penetapan itu. Dan diawasi 
langsung oleh atasan penuntut umum terhadap pelaksanaan kesepakatan diversi. Sementara Pembimbing Kemasyarakatan melakukan pendampingan, pembimbingan, dan pengawasan pelaksanaan kesepakatan Diversi. apabila diperlukan, Pembimbing Kemasyarakatan dan Pekerja Sosial Profesional dapat melaksanakan rehabilitasi dan reintegrasi sosial terhadap Anak bekerja sama dengan lembaga terkait.

Selanjutnya Pembimbing Kemasyarakatan menyusun laporan pelaksanaan kesepakatan Diversi untuk disampaikan pada atasan langsung Penuntut Umum. Laporan itu disampaikan secara ringkas dalam jangka waktu paling lama 1 x 24 (satu kali dua puluh empat) jam terhitung sejak kesepakatan diversi selesai dilaksanakan. Dan dalam jangka waktu paling lama 3 x 24 (tiga kali dua puluh empat) jam terhitung sejak kesepakatan diversi selesai dilaksanakan.

Penuntut Umum menerbitkan surat ketetapan penghentian penuntutan paling lama 3 (tiga) hari terhitung sejak tanggal diterimanya surat penetapan pengadilan, jika kesepakatan diversi berbentuk perdamaian tanpa ganti kerugian atau penyerahan kembali anak kepada orang tua/wali, dalam jangka waktu paling lama 5 (lima) hari terhitung sejak tanggal kesepakatan diversi selesai dilaksanakan, jika kesepakatan diversi berupa pembayaran ganti kerugian, pengembalian pada keadaan semula, atau pelayanan masyarakat, dalam jangka waktu paling lama 5 (lima) hari terhitung sejak tanggal kesepakatan diversi selesai dilaksanakan, jika kesepakatan diversi berupa keikutsertaan anak dalam pendidikan atau pelatihan di lembaga pendidikan atau LPKS, Surat ketetapan penghentian penuntutan sekaligus memuat penetapan status barang bukti sesuai dengan penetapan Ketua Pengadilan Negeri. Kemudian surat ketetapan penghentian penuntutan itu dikirimkan kepada Ketua Pengadilan Negeri beserta laporan proses diversi dan berita acara pemeriksaan dengan tembusan kepada anak dan orang tua/wali, korban, Anak Korban dan/atau orang tua/Wali, Penyidik, Pembimbing Kemasyarakatan, dan Pekerja Sosial Profesional.

Dalam hal kesepakatan Diversi tidak dilaksanakan dalam jangka waktu yang telah ditentukan, Pembimbing Kemasyarakatan melaporkan secara tertulis kepada atasan langsung Penuntut Umum untuk ditindaklanjuti dalam proses peradilan pidana dengan tembusan kepada Ketua Pengadilan Negeri setempat. Dan segera mungkin dalam jangka waktu paling lama 7 (tujuh) hari Penuntut Umum melimpahkan perkara kepada pengadilan (Sinaga, 2016).

Untuk mengetahui pelaksanaan diversi di Kejaksaan Negeri di Provinsi Gorontalo berikut ini adalah data pelaksanaan diversi pada kejaksaan negeri di tiga lokasi penelitian sejak tahun 2016 sampai dengan tahun 2019 dapat dilihat pada tabel berikut ini :

Tabel 2. Pelaksanaan Diversi di Tingkat Kejaksaan Negeri Tahun 2016-2019

\begin{tabular}{|c|c|c|c|c|c|c|c|}
\hline \multirow{3}{*}{ No. } & \multirow{3}{*}{ Tahun } & \multicolumn{6}{|c|}{ Lokasi Penelitian } \\
\hline & & \multicolumn{2}{|c|}{ Kejari Gorontalo } & \multicolumn{2}{|c|}{$\begin{array}{c}\text { Kejari Kota } \\
\text { Gorontalo }\end{array}$} & \multicolumn{2}{|c|}{$\begin{array}{c}\text { Kejari Bone } \\
\text { Bolango }\end{array}$} \\
\hline & & $\begin{array}{l}\text { Jumlah } \\
\text { Perkara }\end{array}$ & Diversi & $\begin{array}{l}\text { Jumlah } \\
\text { Perkara }\end{array}$ & Diversi & $\begin{array}{l}\text { Jumlah } \\
\text { Perkara }\end{array}$ & Diversi \\
\hline 1. & 2016 & 11 & 8 & 6 & 1 & 7 & 3 \\
\hline 2. & 2017 & 2 & o & 5 & 1 & 16 & 7 \\
\hline 3. & 2018 & 1 & 1 & 5 & o & 5 & o \\
\hline 4. & 2019 & 10 & 1 & 17 & 1 & 15 & 3 \\
\hline \multicolumn{2}{|c|}{ Jumlah } & 24 & 10 & 33 & 3 & 43 & 13 \\
\hline
\end{tabular}

Sumber: Data primer diolah tahun 2020 
Berdasarkan data diatas dari tahun 2016 sampai dengan tahun 2019 di tiga lokasi penelitian menunjukkan bahwa kasus anak yang berkonflik dengan hukum yang masuk pada Kejaksaan Negeri di tiga lokasi berjumlah 100 kasus, sementara jumlah yang berhasil di diversi sebanyak 26 kasus. Merujuk pada data ini artinya bahwa dari 100 kasus anak yang berkonflik dengan hukum, sebanyak 74 kasus yang tidak dilaksanakan diversi atau dengan kata lain gagal diversi. Kejaksaan Negeri Bone Bolango paling banyak dalam menyelesaikan kasus anak yang berkonflik dengan hukum melalui diversi yaitu sebanyak 13 kasus dari 43 kasus anak, kemudian Kejaksaan Gorontalo sebanyak 10 kasus dari 14 kasus anak dan Kejaksaan Gorontalo Kota paling sedikit penyelesaian kasus anak yang diselesaikan dengan cara diversi yaitu hanya 3 kasus dari 33 kasus anak yang berkonflik dengan hukum.

Persentase perbandingan penyelesaian anak yang berkonflik dengan hukum melalui diversi dengan tidak dilaksanakan diversi atau gagal diversi dapat dilihat pada diagram berikut ini :

\section{Diagram 2}

Persentase Keberhasilan Diversi Di Kejaksaan Negeri

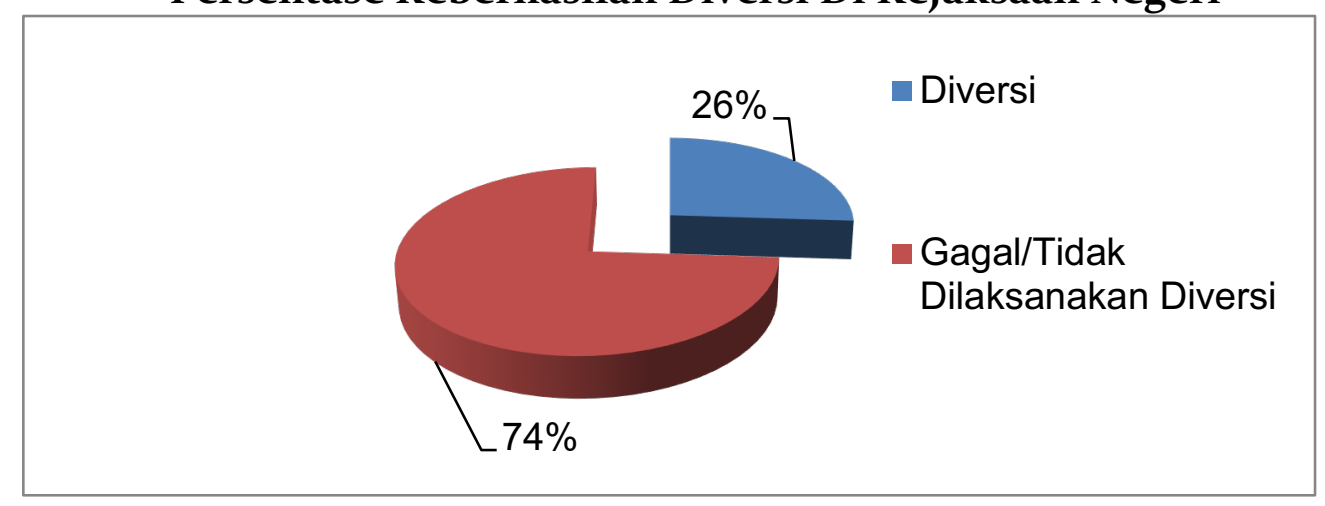

Sumber: Data primer diolah tahun 2020

Sesuai persentase di atas dapat disimpulkan bahwa kasus anak yang berkonflik dengan hukum ditingkat Kejaksaan Negeri dalam penyelesaiannya sebagian besar tidak dapat diselesaikan dengan cara diversi yaitu sebanyak 74 persen, sedangkan yang berhasil di diversi hanya 26 persen. Data ini menunjukkan bahwa penyelesaian kasus anak yang berkonflik dengan hukum melalui diversi belum maksimal atau tidak efektif di tingkat Kejaksaan Negeri di Provinsi Gorontalo.

Berdasarkan wawancara dengan ibu Fenny Haslizarni selaku Jaksa Fungsional pada Kejaksaan Negeri Kota Gorontalo, mengatakan bahwa upaya pelaksanaan diversi untuk kasus anak yang berkonflik dengan hukum ditingkat Kejaksaan Negeri kota Gorontalo memang terbilang sedikit ini dikarenakan diversi telah berhasil dilaksanakan ditingkat penyidikan kepolisian selain itu juga kasus-kasus seperti narkoba, pencabulan dan kasus panah wayar yang marak di kota Gorontalo yang melibatkan anak sebagai pelaku tidak dapat diupayakan diversi.

Masih berdasarkan Fenny Haslizarni selaku Jaksa Fungsional pada Kejaksaan Negeri Kota Gorontalo, mengatakan selama anak dalam masa penanganan kejaksaan, maka pihak kejaksaan melakukan penahanan. Adapun penahanan yang dilakukan di kejaksaan yaitu berdasarkan ketentuan pasal 34 UUSPPA bahwa proses penahanan yang dilakukan oleh pihak penuntut untuk kepentingan penuntutan yaitu paling lama 5 (lima) hari. Apabila dalam waktu 5 (lima) hari tidak selesai maka akan dilakukan perpanjangan hingga 5 (lima) hari. Dalam waktu 10 (sepuluh) hari penuntut umum harus melimpahkan berkas perkara ke 
pengadilan negeri. Dalam Keputusan Bersama tentang Penanganan Anak Yang Berhadapan Dengan Hukum pada Pasal 13 huruf e juga dijelaskan Penuntut Umum dapat melakukan penuntutan dengan acara pendekatan keadilan restoratif.

Dalam melakukan penuntutan yang dilakukan terhadap anak yang melakukan tindak pidana harus dilihat dari unsur-unsur pembuktian dan memperhatikan umur anak tersebut dan dalam penuntutan pidana penjara paling lama adalah $1 / 2$ dari minimum ancaman pidana penjara bagi orang dewasa, karena hak-hak anak telah dilindungi dalam Undang-Undang. Keputusan jaksa penuntut umum melakukan tuntutan pidana karena sejak awal jaksa penuntut umum menilai bahwa anak telah memenuhi unsur pidana dan orang tua anak tidak dapat melakukan pembinaan dan pengawasan terhadap anak. Oleh karena itu, jaksa melakukan penuntutan guna menegakkan keadilan. Tetapi dalam penuntutan yang diberikan untuk anak tersebut bukan untuk memberikan efek jera terhadap anak tersebut tetapi hanya untuk memberikan pembelajaran terhadap anak tersebut. Yang menarik dalam beberapa kasus orang tua malah mendorong anaknya untuk ditahan dan diproses sebagaimana mestinya pelaku tindak pidana sampai di bina di lembaga khusus anak, hal ini setelah ditelusuri ternyata anak yang bersangkutan memang sangat nakal sampai orang tua sudah tidak mampu lagi untuk membina anak tersebut.

Kejaksaan Negeri Gorontalo Kota telah melakukan upaya restoratif justice dan diversi sebab merupakan kewajiban yang dilakukan karena bertujuan untuk mencapai perdamaian antara korban dan anak, menyelesaikan perkara anak diluar proses peradilan, menghindarkan anak dari perampasan kemerdekaan, mendorong masyarakat untuk berpartisipasi, dan menanamkan rasa bertanggungjawab kepada anak.

\section{Pelaksanaan Diversi di Tingkat Pengadilan Negeri}

Putusan Mahkamah Konstitusi menilai bahwa Pasal 96, Pasal 100, dan Pasal 101 UUSPPA yang menentukan ancaman pidana kepada pejabat khusus dalam penyelenggaraan SPPA, yaitu hakim, pejabat pengadilan, penyidik, dan penuntut umum, menurut Mahkamah, bukan saja tidak merumuskan ketentuan-ketentuan konstitusional mengenai kemerdekaan kekuasaan kehakiman dan independensi pejabat khusus yang terkait (hakim, penuntut umum, dan penyidik anak), yakni memberikan jaminan hukum bagi penyelenggaraan peradilan yang merdeka, tetapi lebih dari itu juga telah melakukan kriminalisasi terhadap pelanggaran administratif dalam penyelenggaraan SPPA yang tentu memberikan dampak negatif terhadap pejabat-pejabat khusus yang menyelenggarakan SPPA. Dampak negatif tersebut adalah dampak psikologis yang tidak perlu, yakni berupa ketakutan dan kekhawatiran dalam penyelenggaraan tugas dalam mengadili suatu perkara. Hal ini menimbulkan ketidakpastian hukum dan ketidakadilan yang berarti bertentangan dengan Pasal 28D ayat (1) UUD 1945 dan kontra produktif dengan maksud untuk menyelenggarakan SPPA dengan diversinya secara efektif dan efisien dalam rangka keadilan restoratif.

Dalam tahap persidangan, ketua pengadilan wajib menetapkan Hakim atau majelis hakim untuk menangani perkara anak paling lama 3 (tiga) hari setelah menerima berkas perkara dari penuntut umum. Hakim wajib mengupayakan diversi paling lama 7 (tujuh) hari setelah ditetapkan oleh ketua pengadilan negeri sebagai hakim. Diversi dilaksanakan paling lama 30 (tiga puluh) hari (Prasetyo, 2015).

Musyawarah Diversi dilaksanakan di pengadilan negeri bertempat di ruang khusus mediasi anak yang dipimpin oleh Hakim sebagai fasilitator dan Pembimbing Kemasyarakatan sebagai wakil fasilitator. Musyawarah Diversi dihadiri oleh Anak dan/atau orang tua/Wali, korban, 
Anak Korban dan/atau orang tua/Wali, dan/atau Pekerja Sosial Profesional. Dalam hal proses musyawarah Diversi tidak mencapai kesepakatan, Hakim membuat laporan dan berita acara proses Diversi. Apabila musyawarah Diversi Perkara Anak tidak mencapai kesepakatan, dilanjutkan ke tahap persidangan. Dalam hal musyawarah diversi mencapai kesepakatan, Surat Kesepakatan diversi ditandatangani oleh Anak dan/atau orang tua/Wali, korban, Anak Korban dan/atau orang tua/Wali, Hakim, Pembimbing Kemasyarakatan, dan/atau Pekerja Sosial Profesional. Kemudian seluruh proses pelaksanaan diversi dicatat dalam berita acara diversi. Kemudian hakim menyampaikan Surat Kesepakatan Diversi dan berita acara Diversi kepada Ketua Pengadilan Negeri untuk dikeluarkan penetapan kesepakatan diversi sekaligus menetapkan status barang bukti dalam jangka waktu paling lama 3 (tiga) hari terhitung sejak tanggal Surat Kesepakatan Diversi ditandatangani. Dalam jangka waktu paling lama 3 (tiga) hari terhitung sejak tanggal penetapan, tembusan surat penetapan itu disampaikan kepada orang tua anak pelaku, pihak korban, Hakim, Penuntut Umum, dan Pembimbing Kemasyarakatan. Hakim meminta para pihak untuk melaksanakan kesepakatan Diversi setelah menerima penetapan.

Ketua Pengadilan Negeri melakukan pengawasan terhadap pelaksanaan kesepakatan diversi dan Pembimbing Kemasyarakatan melakukan pendampingan, pembimbingan, dan pengawasan pelaksanaan kesepakatan diversi. apabila diperlukan, Pembimbing Kemasyarakatan dapat melaksanakan rehabilitasi dan reintegrasi sosial terhadap Anak bekerja sama dengan lembaga terkait.

Penuntut umum mengeluarkan surat ketetapan penghentian penuntutan dengan ketentuan dalam jangka waktu paling lama 3 (tiga) hari terhitung sejak tanggal surat penetapan pengadilan diterima, jika kesepakatan diversi berbentuk perdamaian tanpa ganti kerugian atau penyerahan kembali Anak kepada orang tua/Wali, dalam jangka waktu paling lama 5 (lima) hari terhitung sejak tanggal penetapan penghentian pemeriksaan perkara diterima, jika kesepakatan Diversi berupa pembayaran ganti kerugian, pengembalian pada keadaan semula, atau pelayanan masyarakat, dalam jangka waktu paling lama 5 (lima) hari terhitung sejak tanggal penetapan penghentian pemeriksaan perkara diterima, jika kesepakatan diversi berupa keikutsertaan anak dalam pendidikan atau pelatihan di lembaga pendidikan atau LPKS; atau dalam jangka waktu paling lama 5 (lima) hari terhitung sejak tanggal penetapan penghentian pemeriksaan perkara diterima, jika seluruh kesepakatan diversi telah dilaksanakan.

Surat ketetapan penghentian penuntutan sekaligus memuat penetapan status barang bukti sesuai dengan penetapan Ketua Pengadilan Negeri setempat. Kemudian surat itu dikirimkan kepada hakim dengan tembusan kepada anak dan orang tua/wali, korban, Anak Korban dan/atau orang tua/wali, Pembimbing Kemasyarakatan, Pekerja Sosial Profesional, dan Ketua Pengadilan Negeri setempat. Ada catatan yang harus dipertanyakan terkait masalah diversi ini dalam ketentuan UUSPPA maupun Peraturan Mahkamah Agung tentang diversi, dimana belum diaturnya diversi bagi tindak pidana yang sifatnya victimless atau tidak memiliki korban sebagai pihak terkait. Di Undang-Undang maupun Perma belum mengatur tentang peran diversi dalam mengambil alih kasus-kasus yang sifatnya victimless, seperti narkoba, perjudian dan beberapa tindak pidana lainnya.

Untuk mengetahui pelaksanaan diversi di Pengadilan Negeri di 3 (tiga) lokasi yang penulis teliti, berikut ini adalah tabel jumlah kasus anak yang diselesaikan di Pengadilan Negeri : 
Tabel 3. Pelaksanaan Diversi di Pengadilan Negeri Tahun 2016-2019

\begin{tabular}{|c|c|c|c|c|c|c|c|}
\hline \multirow{3}{*}{ No. } & \multirow{3}{*}{ Tahun } & \multicolumn{6}{|c|}{ Lokasi Penelitian } \\
\hline & & \multicolumn{2}{|c|}{ PN Gorontalo } & \multicolumn{2}{|c|}{$\begin{array}{c}\text { PN Kota } \\
\text { Gorontalo }\end{array}$} & \multicolumn{2}{|c|}{ PN Boalemo } \\
\hline & & $\begin{array}{l}\text { Jumlah } \\
\text { Perkara }\end{array}$ & Diversi & $\begin{array}{l}\text { Jumlah } \\
\text { Perkara }\end{array}$ & Diversi & $\begin{array}{l}\text { Jumlah } \\
\text { Perkara }\end{array}$ & Diversi \\
\hline 1. & 2016 & 14 & 6 & 6 & o & 1 & o \\
\hline 2. & 2017 & 12 & o & 17 & 9 & 1 & o \\
\hline 3. & 2018 & 5 & o & 8 & o & 1 & o \\
\hline 4. & 2019 & 15 & 2 & 17 & 3 & 6 & o \\
\hline \multicolumn{2}{|c|}{ Jumlah } & 46 & 8 & 48 & 12 & 9 & o \\
\hline
\end{tabular}

Sumber : Data primer yang diolah, tahun 2020

Berdasarkan data jumlah anak yang berkonflik dengan hukum sebanyak 103 perkara, yang berhasil diversi sebanyak 20 dan yang gagal/tidak dilaksanakan diversi 83 perkara.

Adapun persentase perbandingan penyelesaian anak yang berkonflik dengan hukum melalui diversi dengan tidak dilaksanakan diversi atau gagal diversi bisa dilihat pada diagram di bawah ini :

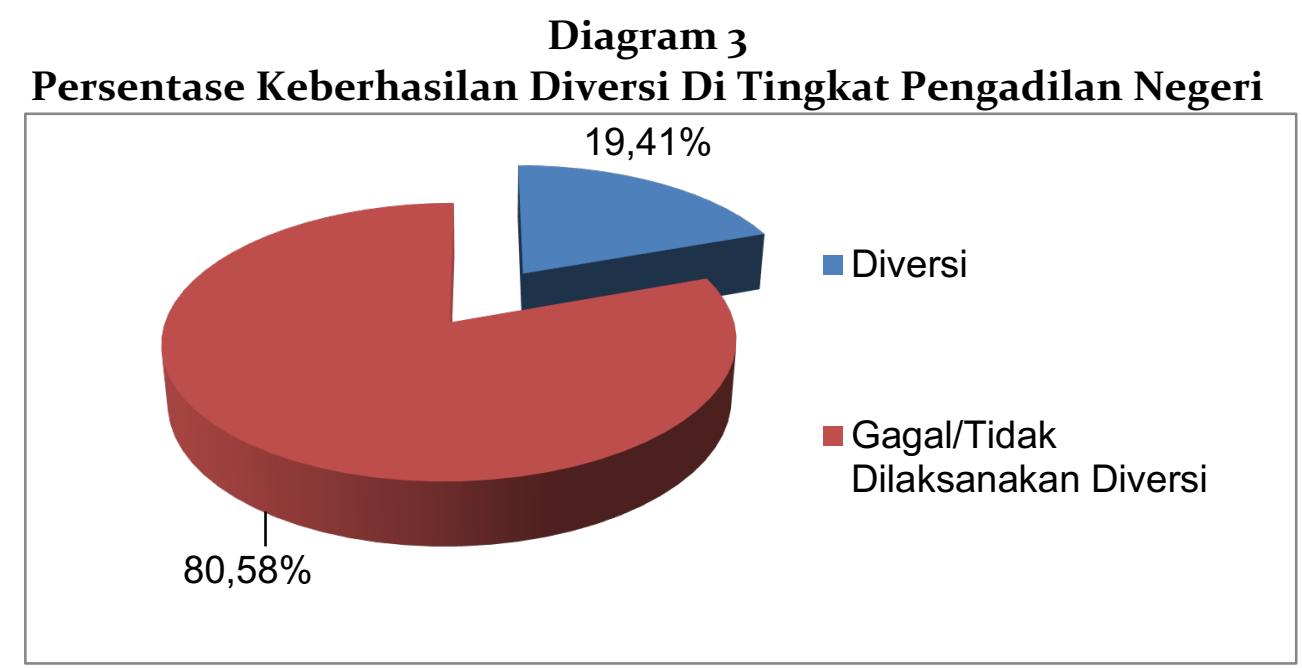

Sumber : Data primer yang diolah, tahun 2020

Berdasarkan data tabel dan diagram di atas, total perkara anak yang masuk sejak Tahun 2016 sampai dengan Tahun 2019 terdapat sebanyak 103 perkara anak yang ditangani di 3 Pengadilan Negeri. Dari jumlah perkara yang masuk selama 4 tahun terakhir, yang dapat berhasil di diversikan sebanyak 20 perkara anak. Apabila di persentasekan jumlah perkara anak yang berhasil di diversikan adalah sebanyak 19,41\%. Sedangkan jumlah perkara anak yang gagal untuk menempuh diversi sebanyak 83 perkara. Dan apabila dipersentasekan, setara dengan $80,58 \%$.

Dalam konteks penyelesaian perkara melalui diversi, apabila pencapaian keberhasilan perkara dengan diversi lebih dari 50\% maka dapat dikatakan bahwa ketentuan tersebut efektif diterapkan. Ini di karenakan apabila dapat berhasil hingga 50\% lebih perkara yang diselesaikan melalui jalur diversi, maka akan sangat mengurangi jumlah perkara yang akan disidangkan di pengadilan. Dengan demikian dapat dikatakan bahwa penerapan diversi di 
pengadilan Negeri yang penulis teliti belum dapat dikatakan efektif karena belum mencapai persentase keberhasilan lebih dari 50\%.

Hal ini juga diperkuat dengan hasil wawancara dengan salah satu hakim peradilan anak pada Pengadilan Negeri Kota Gorontalo yaitu ibu Fitri Noho yang menyatakan bahwa diversi dapat dinyatakan efektif apabila persentase keberhasilan penyelesaian perkara menggunakan diversi sudah mencapai 51\% lebih. Sependapat dengan hasil wawancara diatas, penulis menarik kesimpulan bahwa pelaksaan diversi di tingkat Pengadilan Negeri di provinsi Gorontalo tidak efektif, hal ini berdasarkan indikator capaian tidak berhasil atau gagalnya diversi yang dilaksanakan seperti yang tertera pada gambaran tabel diatas dan hasil analisa penulis.

Berdasarkan wawancara dengan hakim anak sekaligus ketua Pengadilan Negeri Limboto bapak Ahmad Samuar, menyatakan bahwa pelaksanaan proses diversi yang dijalankan selama ini di Pengadilan Negeri Limboto sudah mengikuti tahapan-tahapan yang sesuai dengan prosedur UUSPPA dan Perma Nomor 4 tahun 2014 tentang Pedoman Pelaksanaan Diversi di Pengadilan, yakni melalui proses persiapan diversi, musyawarah diversi, hingga pembuatan kesepakatan hasil diversi baik diversi berhasil maupun gagal. Selain itu, adanya itikad baik para pihak juga berperan besar dalam mendukung terlaksananya proses diversi. Sedangkan di sisi lain, masih lemahnya persentase keberhasilan diversi dipengaruhi oleh beberapa faktor yang menghambat penerapan diversi yaitu faktor dari para pihak yang kaitannya dengan ego internal para pihak maupun faktor eksternal dari pihak-pihak yang berperkara. Kemudian faktor lainnnya adalah kurangnya tenaga fasilitator yang mampu memfasilitasi pelaksanaan proses diversi dan juga faktor lainnya adalah perkara-perkara yang terjadi di Pengadilan Negeri Limboto bukan tergolong dalam perkara yang dapat di diversikan.

Hal-hal penting dalam Perma Nomor 4 Tahun 2014 tentang Pedoman Pelaksanaan Diversi Dalam Sistem Peradilan Pidana Anak yaitu pengaturan mengenai kewajiban hakim dalam mengupayakan diversi dalam perkara anak yang didakwa melakukan tindak pidana dengan ancaman penjara 7 tahun. Juga kepada anak yang didakwa melakukan tindak pidana dengan ancaman penjara pidana 7 tahun atau lebih dalam bentuk surat dakwaan subsidaritas, alternatif, akumulatif, maupun kombinasi (gabungan) (Ningtias, Sampara \& Djanggih, 2020).

Berdasarkan hasil wawancara dengan dengan hakim anak sekaligus ketua Pengadilan Negeri Limboto bapak Ahmad Samuar, menyatakan bahwa dakwaan yang disusun secara alternatif, subsidaritas, kumulatif dan kombinasi, diversi tetap dilakukan anak yang didakwa dengan dakwaan di bawah 7 (tujuh) tahun, akan tetapi apabila dalam proses diversi ditemukan perbuatan yang mengarah pada unsur-unsur yang didakwa diatas 7 (tujuh) tahun, maka fasilitator diversi harus berani mengambil sikap, mau dilaksanakankan diversi atau tidak. Oleh karena itu, penentuan diversi harus bersikap hati-hati dan tergantung kasusnya.

Dari hasil kajian penulis ada persoalan yang bisa saja muncul apabila kesepakatan diversi tidak dilaksanakan sementara perkara tersebut telah dihentikan prosesnya, misalnya pelaku harus membayar sejumlah ganti kerugian kepada korban tetapi pelaku kemudian tidak mampu membayar, apakah perkara tersebut dapat dibuka kembali proses hukumnya, menggunakan instrument hukum perdata atas dasar wanprestasi tentu akan menyita waktu yang cukup lama, sehingga bisa mengganggu psikologis anak karena selalu dikaitkan dengan persidangan. 


\section{KESIMPULAN}

Pelaksanaan diversi dalam perkara tindak pidana yang dilakukan oleh anak yaitu diversi menekankan pada pemulihan kembali seperti pada keadaan yang semula, bukan bersifat pembalasan, dimana pelaksanaannya dilatarbelakangi keinginan untuk menghindari stigma anak sebagai pelaku kejahatan dan menghindari efek negatif terhadap jiwa dan perkembangan anak tersebut dalam keterlibatannya dalam sistem peradilan pidana. Pelaksanaan diversi di wilayah hukum provinsi Gorontalo belum efektif dikarenakan masih banyak anak yang melakukan tindak pidana, ditangani secara prosedur formal dengan kata lain gagal atau tidak dilaksanakan diversi.

\section{SARAN}

1. Pemerintah segera melengkapi sarana dan prasarana demi terjaminnya perlindungan anak, dan pemerintah hendaknya membentuk lembaga-lembaga dalam menangani program-program diversi yang di dukung oleh pemerintah, penegak hukum dan juga melibatkan organisasi sosial/LSM dan para pemerhati perlindungan anak.

2. Perlunya dilakukan sosialisasi secara massif kepada masyarakat betapa pentingnya perlindungan anak, serta mendorong masyarakat untuk berpartisipasi dan menanamkan rasa tanggung jawab kepada anak dapat diwujudkan dengan baik

\section{DAFTAR PUSTAKA}

Chandra, A., Baharuddin, H., \& Djanggih, H. (2020). Pelaksanaan Fungsi Kejaksaan Dalam Penerapan Diversi Terhadap Anak Yang Berkonflik Dengan Hukum. Journal of Lex Generalis (JLG), 1(1), 88-100.

Dewantary, Z. R. (2016). Keadilan Restoratif Dan Pembatasan Diversi Pada Undang-Undang Nomor 11 Tahun 2012 Tentang Sistem Peradilan Pidana Anak. Veritas et Justitia, 2(2), 303-326.

Fikri, R. A. (2020). Implementasi Diversi Terhadap Anak Yang Berhadapan Dengan Hukum Ditinjau Dari Undang-Undang Nomor 11 Tahun 2012 Tentang Sistem Peradilan Pidana Anak. Jurnal Abdi Ilmu, 13(2), 72-81.

Murdiana, E. (2017). Keadilan Anak Perspektif Undang-Undang No. 11 Tahun 2012 tentang Sistem Peradilan Anak. Tapis: Jurnal Penelitian Ilmiah, 1(02), 255-271.

Ningtias, D. R., Sampara, S., \& Djanggih, H. (2020). Diversi Sebagai Bentuk Penyelesaian Perkara Pidana Anak. Journal of Lex Generalis (JLG), 1(5), 633-651.

Nurhaliza, R., Liyus, H., \& Wahyudi, D. (2020). Pelaksanaan Kesepakatan Diversi Pada Tingkat Penyidikan Dalam Sistem Peradilan Anak. Pampas: Journal of Criminal Law, 1(1), 110-124.

Pradityo, R. (2016). Restorative Justice dalam Sistem Peradilan Pidana Anak. Jurnal Hukum dan Peradilan, 5(3), 319-330.

Prasetyo, T. (2015). Penerapan Diversi Terhadap Tindak Pidana Anak Dalam Sistem Peradilan Pidana Anak. Refleksi Hukum: Jurnal Ilmu Hukum, 9(1), 1-14.

Ratomi, A. (2013). Konsep prosedur pelaksanaan diversi pada tahap penyidikan dalam penyelesaian tindak pidana yang dilakukan oleh anak. Arena Hukum, 6(3), 394-407. 
Sinaga, E. Y. (2016). Penerapan Diversi Pada Tahap Penuntutan Dalam Sistem Peradilan Pidana Anak. Badamai Law Journal, 1(2), 201-220.

Tampubolon, S., \& Jamba, P. (2020). Analisis Yuridis Pelaksanaan Diversi Dalam Tahap Penyidikan Kepolisian Ditinjau Dari Sistem Peradilan Pidana Anak. Ensiklopedia Sosial Review, 2(2), 140-145.

Wicaksono, A. H., \& Pujiyono, P. (2015). Kebijakan Pelaksanaan Diversi Sebagai Perlindungan Bagi Anak Yang Berkonflik dengan Hukum Pada Tingkat Penuntutan Di Kejaksaan Negeri Kudus. LAW REFORM, 11(1), 12-42. 